\title{
Effect of $\alpha_{2}$-adrenoceptor agonists on gastric pepsin and acid secretion in the rat
}

\author{
Khaddouj Tazi-Saad, Jacques Chariot, *Mario Del Tacca \& 'Claude Rozé
}

INSERM U239, Faculté de Médecine X Bichat, 16 Rue H Huchard, 75018 Paris, France, and *Institute of Pharmacology, Medical School of the University, Via Roma 55, 56100 Pisa, Italy

1 The purpose of the present study was to analyze the effects of the $\alpha_{2}$-adrenoceptor agonists clonidine, guanabenz, detomidine and medetomidine on pepsin secretion in conscious rats provided with gastric chronic fistula and to compare this with acid secretion.

2 Basal interdigestive gastric secretion, which is mainly neurally driven in the rat, and the secretion directly stimulated by the two main stimulants of chief cells, cholecystokinin octapeptide (CCK8) and methacholine, were studied.

3 Basal secretion of pepsin and acid was inhibited by all four drugs with comparable $\mathrm{EC}_{50} \mathrm{~s}$.

4 CCK-stimulated pepsin and acid secretion was less sensitive than basal pepsin and acid secretion to $\alpha_{2}$-adrenoceptor inhibition.

5 Methacholine-stimulated pepsin and acid secretion was not changed by clonidine and guanabenz; methacholine-stimulated acid was even marginally increased by clonidine.

6 These results do not favour the presence of $\alpha_{2}$-receptors on chief cells in the rat stomach. They rather suggest that pepsin inhibition by $\alpha_{2}$-adrenoceptor agonists is indirect and due to central or peripheral inhibition of the discharge of nerve fibres activating pepsin secretion.

Keywords: Gastric fistula rats; pepsin secretion; acid secretion; $\alpha_{2}$-adrenoceptors; clonidine; guanabenz; detomidine; medetomidine

\section{Introduction}

Both direct inhibition and indirect stimulation of gastric acid secretion by $\alpha_{2}$-adrenoceptor agonists have been reported. Inhibition had both central and peripheral components (Taylor \& Mir, 1982; Pascaud et al., 1983), whereas stimulation might take place through activation of peripheral histamine receptors (Del Tacca et al., 1982; Soldani et al., 1984). By comparison, the influence of $\alpha_{2}$-adrenoceptor agonists on pepsin secretion is poorly documented and the presence of $\alpha_{2}$-adrenoceptors on chief cells has not been reported.

The purpose of this study was to determine the effects of four $\alpha_{2}$-adrenoceptor agonists, clonidine, guanabenz, detomidine and medetomidine, on gastric pepsin secretion in vivo, and compare it with acid secretion. The experiments were conducted in gastric fistula rats under basal conditions, a situation in which gastric secretion is mainly neurally driven, and after direct stimulation of chief cells by cholecystokinin octapeptide (CCK8) or methacholine, two potent stimulants of pepsin secretion (Tazi-Saad et al., 1992).

\section{Methods}

\section{Animals}

Male Wistar rats (Iffa Credo, Les Oncins, F-69210 L'Arbresle, France), weighing $300 \pm 20 \mathrm{~g}$, were used in these studies. They were maintained in the laboratory on a commercial autoclaved pelleted chow (UAR 113, Alimentation Rationnelle, Villemoisson, F-91360 Epinay sur Orge, France).

\section{Gastric chronic fistula}

After premedication with $10 \mathrm{mg} \mathrm{kg}^{-1}$ of acepromazine i.p. (Vetranquil, Clin Midy, F-45142, St Jean de la Ruelle,

\footnotetext{
${ }^{1}$ Author for correspondence.
}

France), the rats were anaesthetized with $50 \mathrm{mg} \mathrm{kg}^{-1}$ ketamine i.p. (Imalgène 500, Rhône Mérieux, F-69002 Lyon, France). A gastric fistula was set up following the method of Emås et al. (1981): a seromuscular purse was prepared in the ruminal part of the stomach, and a Thomas cannula was inserted and secured in place with the help of a square pad of synthetic felt $1.5 \times 1.5 \mathrm{~cm}$ (Dacron felt, USCI, U.S.A.).

\section{Salivary secretion}

In experiments with methacholine, salivary secretion was also stimulated and gastric secretion was therefore contaminated by salivary bicarbonate. To correct for this contamination, salivary secretion was measured in separate experiments. Under ether anaesthesia, a polyethylene catheter (Biotrol No 13) was introduced in the lower oesophagus through a ruminal incision, secured in place by two ligatures at the level of the cardia and rumen, and conducted through the abdominal wall. The muscle and skin were sutured, the rat was placed in a Bollman cage, and an infusion catheter was inserted in a tail vein. After $2 \mathrm{~h}$ of post anaesthesia recovery, saliva was collected as $40 \mathrm{~min}$ fractions in $5 \mathrm{ml}$ graduated tubes. Methacholine was infused in successive increasing doses under the same conditions as in gastric fistula rats. The volume of saliva samples was measured to the nearest $0.1 \mathrm{ml}$. Bicarbonate was determined by an auto-analyzer method (Chariot \& Rozé, 1976).

\section{Secretory tests}

Two weeks of post-operative recovery were allowed before the secretory tests began. During this period, the rats were trained to stand quiet in the Bollman cages during three sham-experiments. Secretory tests were then performed no more than once a week. After a $24 \mathrm{~h}$ fasting period with drinking water ad libitum, the gastric cannula was opened and the stomach was rinsed with water prewarmed at $37^{\circ} \mathrm{C}$. A plastic prolongator was screwed onto the gastric cannula 
and a small diameter polyethylene catheter with lateral holes was introduced and secured in the cannula. This catheter helped to collect the gastric juice safely, by guiding it drop by drop into the collecting tube. The rats were placed in Bollman cages, and an infusion catheter was inserted in a tail vein and secured with adhesive tape. A venous infusion of $\mathrm{NaCl} 0.9 \% \quad w / v$ was then started. Gastric secretion was collected as $40 \mathrm{~min}$ samples in tared tubes. The weight of gastric juice was measured, and accepted as a measure of gastric volume, assuming that $1 \mathrm{ml}=1 \mathrm{~g}$. Two $40 \mathrm{~min}$ samples were collected before injecting any substance. The mean of these two samples was taken as representative of basal secretion.

\section{Acid secretion}

Acid was titrated to $\mathrm{pH}=7.0$ with $\mathrm{NaOH} 4 \mathrm{mM}$, on $0.1 \mathrm{ml}$ samples, with an automatic titrator (Metrohm AG, 9100 Herisau, Switzerland). When the $\mathrm{pH}$ of gastric samples was greater than or equal to 5.0 , the samples were immediately acidified with $20 \mu \mathrm{l} \mathrm{HCl}(6 \mathrm{M})$ per $\mathrm{ml}$ of gastric juice, in order to protect pepsin activity, which rapidly fades away in solutions of $\mathrm{pH}>5$.

\section{Pepsin secretion}

Pepsin activity was determined by a semi-automated method derived from the method proposed by Anson \& Mirsky (1933), which involves two successive steps: (1) Pepsin present in the samples was allowed to digest an aqueous solution of $2.5 \%$ haemoglobin (Sigma, St Louis, MO, U.S.A.), $\mathrm{pH}=1.7$, for $3 \mathrm{~min}$ at $37^{\circ} \mathrm{C}$. The reaction was then stopped by adding $5 \%$ trichloracetic acid (Prolabo, Paris, France), and soluble hydrolysis products were separated by centrifugation. (2) Soluble hydrolysis products were determined with the Folin-Ciocalteu reagent (Merck, West Point, U.S.A.) in a Technicon auto-analyzer, with tyrosine as a standard. Volume of each sample was $50 \mu \mathrm{l}$ for the dosage and $50 \mu \mathrm{l}$ for the blank tube without hydrolysis. Pepsin activity of the gastric juice was determined relative to a control scale of standard purified pepsin (Fluka, Buchs, Switzerland, ref $77152,0.2$ to $1 \mathrm{mg} \mathrm{ml}^{-1}$ ) and was expressed as pepsin units (PU). One unit corresponds to the amount of pepsin releasing $1 \mu \mathrm{mol}$ tyrosine $\mathrm{min}^{-1}$ under the conditions adopted for the study.

\section{Experimental schedules}

Effect of $\alpha_{2}$-adrenoceptor agonists on basal secretion Clonidine, guanabenz, detomidine and medetomidine were administered as successive i.v. infusions of increasing doses $(4.35$, $13.7,43.5 \mathrm{nmol} \mathrm{kg}^{-1} \mathrm{~h}^{-1}$ ), each infused for $80 \mathrm{~min}$. The effect of each dose was measured during the second $40 \mathrm{~min}$ half of the $80 \mathrm{~min}$ infusion period.

The time course of the effect was analyzed on $240 \mathrm{~min}$ i.v. infusions of clonidine $\left(13.7,43.5\right.$ or $\left.137 \mathrm{nmol} \mathrm{kg}^{-1} \mathrm{~h}^{-1}\right)$ or guanabenz $\left(13.7\right.$ or $\left.43.5 \mathrm{nmol} \mathrm{kg}^{-1} \mathrm{~h}^{-1}\right)$. To test the $\alpha_{2}$ specificity of the clonidine effect, the $\alpha_{2}$-adrenoceptor antagonist, idazoxan, was administered as a s.c. injection, $40 \mathrm{~min}$ before the infusion of clonidine had begun.

Effect of clonidine and guanabenz on CCK-stimulated secretion Clonidine $\left(13.7,43.5\right.$ or $\left.137 \mathrm{nmol} \mathrm{kg}^{-1} \mathrm{~h}^{-1}\right)$ or guanabenz (13.7 or $43.5 \mathrm{nmol} \mathrm{kg} \mathrm{g}^{-1} \mathrm{~h}^{-1}$ ) were first infused alone i.v. for $120 \mathrm{~min}$, and then accompanied by CCK, 1.9 and $6 \mathrm{nmol}-$ $\mathrm{kg}^{-1} \mathrm{~h}^{-1}$ as two successive $40 \mathrm{~min}$ infusions. In antagonist experiments, idazoxan was injected s.c., $40 \mathrm{~min}$ before clonidine infusion.

Effect of clonidine and guanabenz on methacholine-stimulated secretion Clonidine or guanabenz were first infused alone i.v. for $120 \mathrm{~min}$, and then accompanied by methacholine, 3100 and $9710 \mathrm{nmol} \mathrm{kg}^{-1} \mathrm{~h}^{-1}$, as two successive $40 \mathrm{~min}$ infusions. Since salivary secretion (a source of fluid and bicarbonate) was stimulated by methacholine, acid secretion was underestimated and volume was overestimated in these experiments. Thus, volume and acid data were corrected for salivary secretion measured in separate experiments: the volume of saliva was subtracted from the total volume of juice collected from the gastric fistula, whereas salivary bicarbonate output was added to gastric acid output, assuming that gastric acid had been stoichiometrically neutralized by salivary bicarbonate. To ensure pepsin stability, all samples from methacholine experiments were immediately acidified with $6 \mathrm{M} \mathrm{HCl} 20 \mu \mathrm{ml}^{-1}$.

\section{Substances tested}

The following substances were used: CCK: Boc-Nle ${ }_{28}-\mathrm{Nle}_{31}-$ $\mathrm{CCK}_{26-33}$ (a gift of J. Martinez, Centre CNRS-INSERM de Pharmacologie Endocrinologie, Montpellier, France), a synthetic analogue of CCK8 the activity of which is equal to that of CCK8 in all models tested to date; methacholine: acetyl- $\beta$-methylcholine chloride (Pharmacie Centrale des Hopitaux, Paris, France); clonidine: a gift of Boehringer (Ingelheim, Germany); guanabenz acetate: Sigma (St Louis, MO, U.S.A.); detomidine hydrochloride and medetomidine hydrochloride: a gift of Farmos (Turku, Finland); idazoxan: a gift of Reckitt and Colman (Kingston upon Hull, GB). All drugs were dissolved in $\mathrm{NaCl} 0.9 \%$. CCK solutions were prepared in $0.9 \% \mathrm{NaCl}$ with $0.3 \%$ bovine serum albumin added.

\section{Expression of results and statistics}

The results are expressed as means \pm standard error of the mean (s.e.mean). The doses causing $50 \%$ inhibition $\left(\mathrm{ED}_{50}\right)$ were calculated from the linear portion of the regression curve of the effect on $\log$ dose, as described by Tallarida \& Murray (1984). Statistical significance of the differences between means was tested by one or two way ANOVA, followed when necessary by a multigroup comparison test (Dunnet or Newman-Keuls). A $P$ value $\leqslant 0.05$ was considered significant.

\section{Results}

\section{Effect of $\alpha_{2}$-adrenoceptor agonists on basal gastric} secretion

Dose-response curves by infusion of successive increasing doses Clonidine, guanabenz, detomidine and medetomidine inhibited in a dose-related way the basal output of acid and pepsin (Figure 1). The inhibition observed with the dose of $43.5 \mathrm{nmol} \mathrm{kg}^{-1} \mathrm{~h}^{-1}$ reached about $90 \%$ of the basal acid and pepsin outputs. The calculated $\mathrm{ED}_{50}$ values (doses causing $50 \%$ inhibition) are shown in Table 1: all four drugs had similar $\mathrm{ED}_{50} \mathrm{~s}$ on volume, acid and pepsin outputs.

Time course of the inhibition produced by clonidine and guanabenz The time course of the inhibition produced by long lasting $(240 \mathrm{~min})$ i.v. infusions of $13.7 \mathrm{nmol} \mathrm{kg}^{-1} \mathrm{~h}^{-1}$ of clonidine or guanabenz was identical with both drugs. The peak inhibition (about $50 \%$ for volume, acid and pepsin) was observed after $120 \mathrm{~min}$ of infusion, and remained at this level until the end of the infusion (not shown). The time course was similar when the clonidine or guanabenz dose was increased to $43.5 \mathrm{nmol} \mathrm{kg}^{-1} \mathrm{~h}^{-1}$ (Figure 2): the peak inhibition was reached after $120 \mathrm{~min}$ of i.v. infusion, and remained approximately constant for the rest of the infusion period. With this latter dose of clonidine, the inhibition at $120 \mathrm{~min}$ was $80 \%$ for volume, and $90 \%$ for acid and pepsin outputs. With this latter dose of guanabenz, the inhibition at $120 \mathrm{~min}$ was $60 \%$ for volume, $90 \%$ for acid, and $80 \%$ for pepsin output (Figure 2). After clonidine $\left(137 \mathrm{nmol} \mathrm{kg}^{-1} \mathrm{~h}^{-1}\right)$, the 

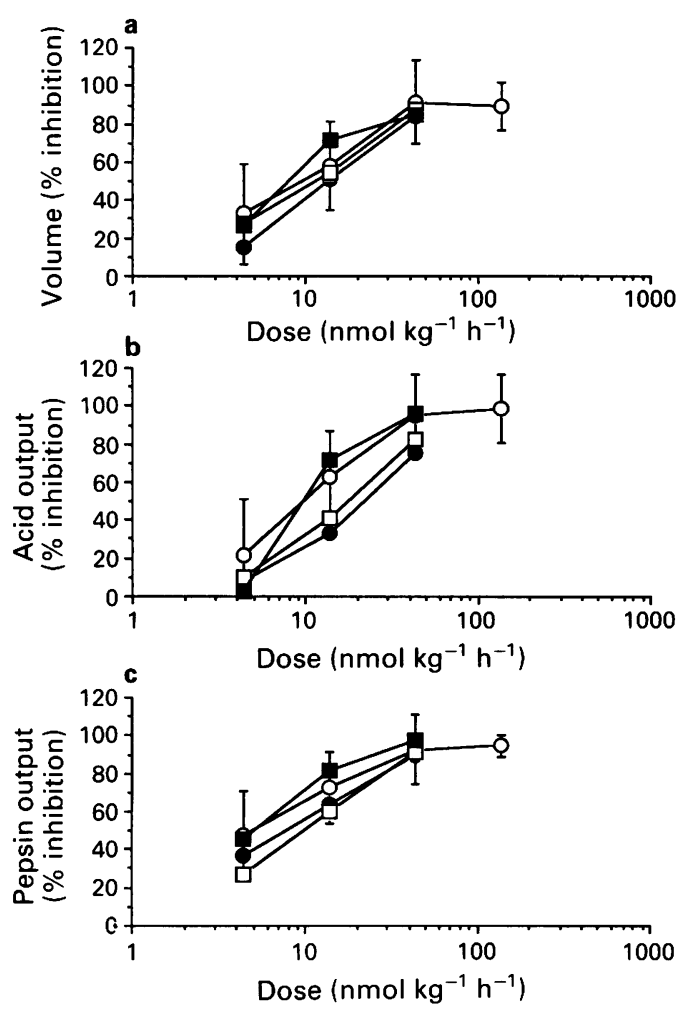

Figure 1 Effects of clonidine $(O)$, guanabenz $(O)$, detomidine $(\square)$ and medetomidine ( $\square$ ), on gastric juice volume (a) and on acid (b) and pepsin (c) outputs as a function of doses in conscious rats provided with gastric chronic fistula. The results are expressed as percentage inhibition of basal secretion. The data show the mean of 6 or 7 rats per group. To increase clarity, the vertical lines showing s.e.mean have been drawn only for the group receiving clonidine.

Table 1 The $\mathrm{ED}_{50}$ values (dose causing $50 \%$ inhibition; nmol kg-1 $\mathrm{h}^{-1}, 95 \%$ confidence limits in parentheses) of clonidine, guanabenz, detomidine and medetomidine on basal gastric secretion

\begin{tabular}{lccc}
\hline Substance & Volume & Acid output & Pepsin output \\
Clonidine & 9.0 & 10.2 & 4.7 \\
& $(5.4-14.8)$ & $(5.9-17.6)$ & $(2.1-10.3)$ \\
Guanabenz & 13.6 & 17.7 & 7.7 \\
& $(10.2-18.2)$ & $(10.7-29.4)$ & $(5.5-10.8)$ \\
Detomidine & 10.6 & 15.1 & 9.8 \\
& $(7.5-14.2)$ & $(9.6-23.7)$ & $(7.1-13.6)$ \\
Medetomidine & 8.9 & 12.2 & 4.8 \\
& $(6.1-13.2)$ & $(8.1-18.3)$ & $(3.6-6.5)$
\end{tabular}

Data are calculated from the experiments shown in Figure $1, n=6$ or 7 rats per group.

inhibition at $120 \mathrm{~min}$ was $87 \%$ for volume, $99 \%$ for acid, and $100 \%$ for pepsin output (Figure 3 ).

Pepsin concentration was significantly decreased by $43.5 \mathrm{nmol} \mathrm{kg} \mathrm{kg}^{-1} \mathrm{~h}^{-1}$ of clonidine or guanabenz (Table 2).

Idazoxan alone did not change basal gastric secretion (not shown), but suppressed the clonidine inhibition of volume, acid and pepsin outputs (Figure 3).

\section{Clonidine and guanabenz on CCK-stimulated gastric secretion}

Volume, acid and pepsin outputs were stimulated in a doserelated way by CCK (Figure 4), while pepsin concentration was decreased (Table 2).

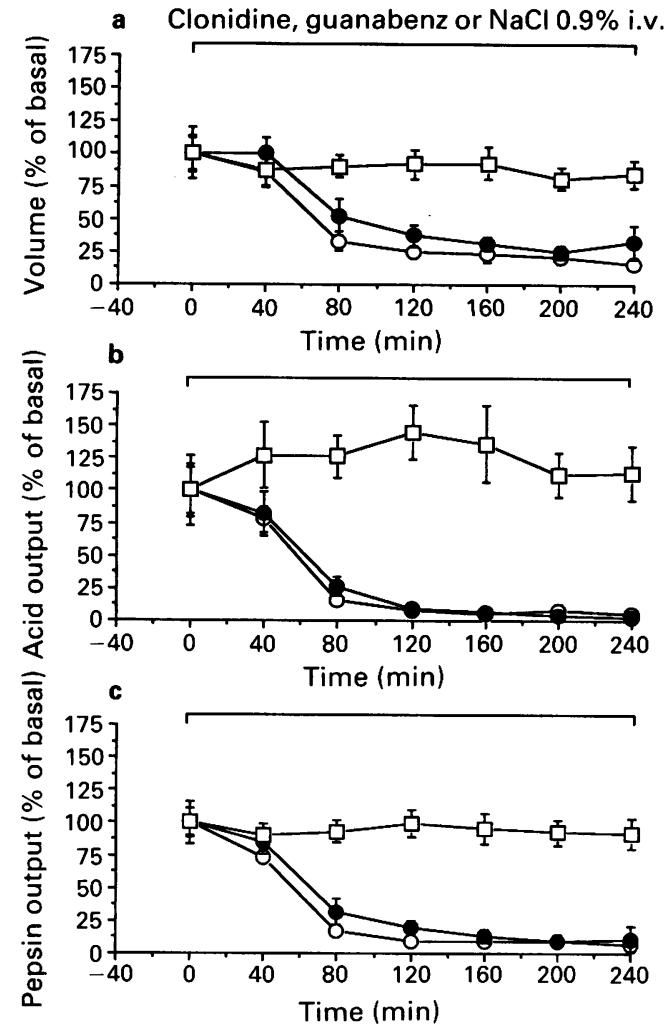

Figure 2 Time course of the inhibitory effect of clonidine $\left(43.5 \mathrm{nmol} \mathrm{kg}^{-1} \mathrm{~h}^{-1}\right.$, i.v., O) and guanabenz $\left(43.5 \mathrm{nmol} \mathrm{kg}^{-1} \mathrm{~h}^{-1}\right.$, i.v., ) on gastric juice volume (a) and on acid (b) and pepsin (c) outputs in conscious rats provided with gastric chronic fistula. The time course of gastric secretion in a control group receiving only $\mathrm{NaCl}(\square)$ is shown for comparison. The results are expressed as percentage inhibition of basal secretion, shown as means of 8 rats per group; vertical bars represent s.e.mean. The average basal levels were: volume $980 \pm 81.3 \mu \mathrm{l} 40 \mathrm{~min}^{-1}$, acid output $75.0 \pm 7.68 \mu \mathrm{mol}$ $40 \mathrm{~min}^{-1}$, pepsin output $10.3 \pm 0.66 \mathrm{PU} 40 \mathrm{~min}^{-1}$.

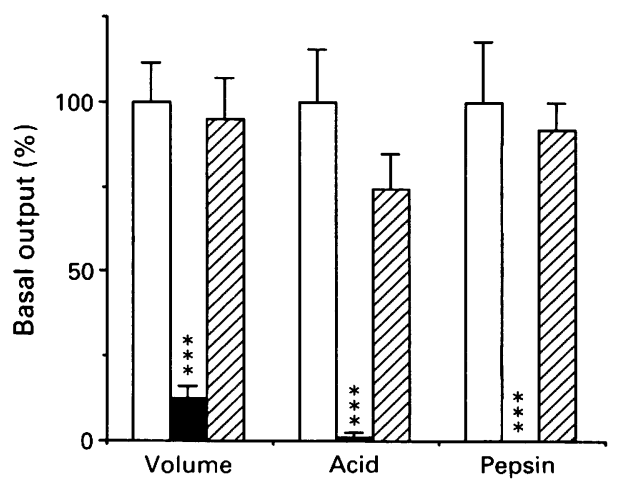

Figure 3 Antagonism by idazoxan ( $3 \mathrm{mg} \mathrm{kg}^{-1}$, s.c. $40 \mathrm{~min}$ before beginning the infusion of clonidine) of the inhibitory effects of clonidine (137 nmol kg $\mathrm{ng}^{-1} \mathrm{~h}^{-1}$, i.v.) on basal volume juice, and on acid and pepsin outputs in conscious rats provided with gastric chronic fistula. Basal secretion $=$ open columns; clonidine $=$ solid columns; idazoxan + clonidine $=$ hatched columns. Means of 8 rats per group. Vertical lines show s.e.mean.

${ }^{* * *} P<0.001$ versus basal level (Dunnett's test)

Clonidine decreased CCK-stimulated gastric secretion (Figure 4). In Figure 4, the probability values refer to the significance of the difference between the three dose levels of

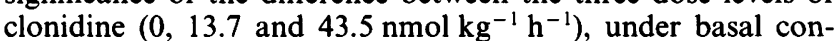
ditions (Control groups) and during the infusion of 1.9 or 
Table 2 Effect of clonidine and guanabenz on pepsin concentration in the gastric juice (PU $\mathrm{ml}^{-1}$ ), in basal conditions (control) and with cholecystokinin (CCK) stimulation

$\begin{array}{cccc}\text { Control } & C C K 1.9 & C C K \text { 6 } & \text { P (CCK effect) } \\ 11.1 \pm 0.9 & 7.6 \pm 0.2 & 8.4 \pm 0.2 & <0.001 \\ 11.0 \pm 0.6 & 7.5 \pm 0.3 & 9.1 \pm 0.5 & <0.001 \\ 5.6 \pm 1.6 & 7.1 \pm 0.9 & 9.1 \pm 0.7 & \mathrm{NS} \\ <0.01 & \mathrm{NS} & \mathrm{NS} & \\ 9.2 \pm 0.2 & 7.8 \pm 0.3 & 9.9 \pm 0.4 & <0.001 \\ 6.0 \pm 1.2 & 8.5 \pm 0.8 & 11.3 \pm 1.3 & <0.05 \\ <0.01 & \mathrm{NS} & \mathrm{NS} & \end{array}$

*Doses are in $\mathrm{nmol} \mathrm{kg}^{-1} \mathrm{~h}^{-1}$. The values are shown as mean \pm s.e.mean of 6 to 16 rats per group. The $P$ levels correspond to the result of the ANOVA between doses of CCK, clonidine or guanabenz. NS: not significant.
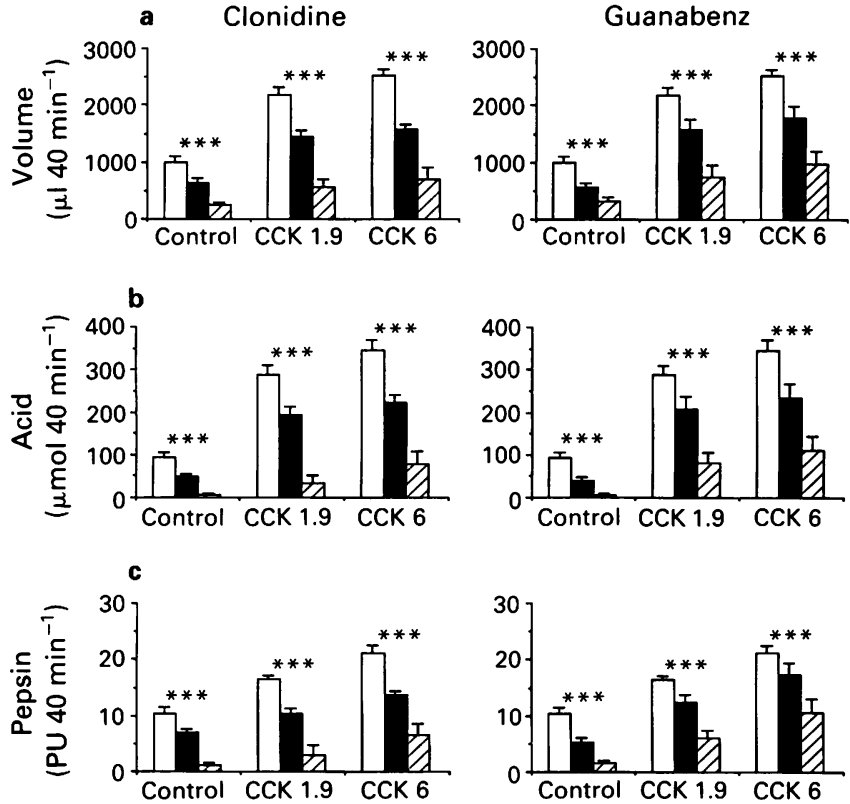

Figure 4 Effects of clonidine (left panel) and guanabenz (righ panel) on gastric juice volume (a) and on acid (b) and pepsin (c) outputs in basal conditions (Control) and under cholecystokinin (CCK) stimulation (1.9 and $6 \mathrm{nmol} \mathrm{kg}^{-1} \mathrm{~h}^{-1}$ ) in conscious rats provided with gastric chronic fistula. The stimulation consisted of two successive $40 \mathrm{~min}$ infusions of CCK 1.9 and $6 \mathrm{nmol} \mathrm{kg}^{-1} \mathrm{~h}^{-1}$ from 120 min after the beginning of clonidine or guanabenz infusion. The doses of clonidine and guanabenz were: zero $=$ open columns: $13.7 \mathrm{nmol} \mathrm{kg}{ }^{-1} \mathrm{~h}^{-1}=$ solid columns and $43.5 \mathrm{nmol} \mathrm{kg}^{-1} \mathrm{~h}^{-1}=$ hatched columns. Means of 6 to 16 rats per group. Vertical lines show s.e.mean.

The probability values, $* * P<0.01$ and $* * * P<0.001$ refer to the significance between the dose levels of clonidine or guanabenz $(0$, 13.7 and $43.5 \mathrm{nmol} \mathrm{kg}^{-1} \mathrm{~h}^{-1}$ ) under basal conditions (control) and under CCK stimulation (1.9 and $6 \mathrm{nmol} \mathrm{kg}^{-1} \mathrm{~h}^{-1}$ ) (ANOVA).
$6 \mathrm{nmol} \mathrm{kg}{ }^{-1} \mathrm{~h}^{-1}$ of $\mathrm{CCK}$. The clonidine $\mathrm{ED}_{50}$ values were twice as great for CCK-stimulated (Table 3) as compared to the basal volume and acid secretion (Table $1, P<0.05$ to 0.01 ), and about four times as great for CCK-stimulated as compared to the basal pepsin output. Pepsin concentration was not significantly changed by clonidine in CCK-treated rats (Table 2). When using large doses of clonidine, CCKstimulated secretion was almost abolished: after $137 \mathrm{nmol}-$ $\mathrm{kg}^{-1} \mathrm{~h}^{-1}$ of clonidine, volume was decreased by $70 \%$, acid output by $99 \%$, and pepsin output by $90 \%$ (Figure 5 ).

Guanabenz (13.7 and $43.5 \mathrm{nmol} \mathrm{kg}^{-1} \mathrm{~h}^{-1}$ ) was also given with CCK (1.9 and $6 \mathrm{nmol} \mathrm{kg}^{-1} \mathrm{~h}^{-1}$ ) (Figure 4). The effects of guanabenz were very similar to those of clonidine on the CCK-stimulated gastric juice volume, acid output and pepsin output. The $\mathrm{ED}_{50}$ values of guanabenz were significantly greater on CCK-stimulated volume and pepsin output (Table 3 ) than on the basal secretion (Table 1). Pepsin concentration was not significantly changed by guanabenz in CCKstimulated rats (Table 2 ).

\section{Idazoxan antagonism of the clonidine inhibition of CCK-stimulated pepsin secretion}

In these studies, a maximally effective dose of $137 \mathrm{nmol}$ $\mathrm{kg}^{-1} \mathrm{~h}^{-1}$ of clonidine was used to ensure a nearly complete inhibition of pepsin secretion. The prior s.c. injection of idazoxan $\left(3 \mathrm{mg} \mathrm{kg}^{-1}\right)$ totally suppressed the clonidineinduced inhibition of pepsin output and decreased the clonidine-induced inhibition of volume $(P<0.05)$ and acid output $(P=0.14)$ (Figure 5).

\section{Effect of clonidine and guanabenz on methacholine-stimulated gastric secretion}

Methacholine stimulated in a dose-related way the volume and the acid and pepsin outputs, as shown in Figure 6 . The volume and acid values were corrected for salivary con-

Table 3 The $\mathrm{ED}_{50}$ values (doses causing $50 \%$ inhibition; $\mathrm{nmol} \mathrm{kg} \mathrm{kg}^{-1} \mathrm{~h}^{-1}, 95 \%$ confidence limits in parentheses) of clonidine and guanabenz on cholecystokinin (CCK)-stimulated gastric secretion

$\begin{array}{lcccc}\text { Substance } & \begin{array}{c}C C K \text { dose } \\ \left(\mathrm{nmol} \mathrm{kg}^{-1} \mathrm{~h}^{-1}\right)\end{array} & \text { Volume } & \text { Acid output } & \text { Pepsin output } \\ \text { Clonidine } & 1.9 & 21.5^{\mathrm{b}} & 19.3^{\mathrm{a}} & 19.4^{\mathrm{c}} \\ & 6 & (16.4-28.2) & (14.9-25.0) & (15.3-24.5) \\ & & 20.9^{\mathrm{b}} & 20.4^{\mathrm{a}} & 22.7^{\mathrm{c}} \\ \text { Guanabenz } & 1.9 & (16.1-27.0) & (15.9-26.1) & (17.5-29.4) \\ & 6 & 26.8^{\mathrm{a}} & 24.4 & 29.2^{\mathrm{c}} \\ & & (16.2-44.0) & (15.4-38.7) & (16.4-52.1) \\ & & 28.8^{\mathrm{a}} & 24.1 & 43.3^{\mathrm{c}} \\ & & (16.0-52.0) & (13.8-42.1) & (15.6-120)\end{array}$

Data are calculated from the experiments shown in Figure $4, n=6$ to 14 rats per group, where a: $P<0.05,{ }^{b}: P<0.01$, ${ }^{\text {c }}$ : $P<0.001$ versus the corresponding $\mathrm{ED}_{50}$ values on basal secretion (Table 1). 


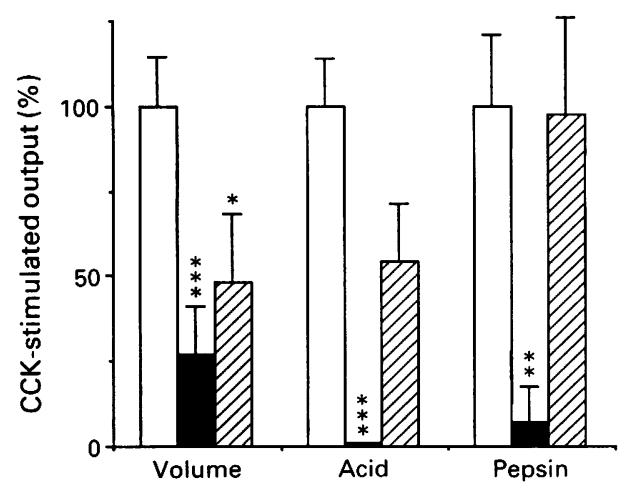

Figure 5 Antagonism by idazoxan $\left(3 \mathrm{mg} \mathrm{kg}^{-1}\right.$, s.c. $40 \mathrm{~min}$ before beginning the infusion of clonidine) of the inhibitory effects of clonidine (137 nmol kg-1 $\mathrm{h}^{-1}$, i.v.) on gastric juice volume, and on acid and pepsin outputs stimulated by CCK $\left(1.9 \mathrm{nmol} \mathrm{kg} \mathrm{kg}^{-1} \mathrm{~h}^{-1}\right.$, i.v., accompanying the infusion of clonidine for $40 \mathrm{~min}$ from $120 \mathrm{~min}$ after the beginning of clonidine infusion) in conscious rats provided with gastric chronic fistula. $\mathbf{C C K}=$ open columns; $\mathrm{CCK}+$ clonidine = solid columns; CCK + idazoxan + clonidine $=$ hatched columns. The results are expressed as percentage of the CCK-stimulated secretion. Means of 8 to 12 rats per group. Vertical lines show s.e.mean.

${ }^{*} P<0.05 ;{ }^{* *} P<0.01 ;{ }^{* * *} P<0.001$ versus group CCK (Dunnett's test).
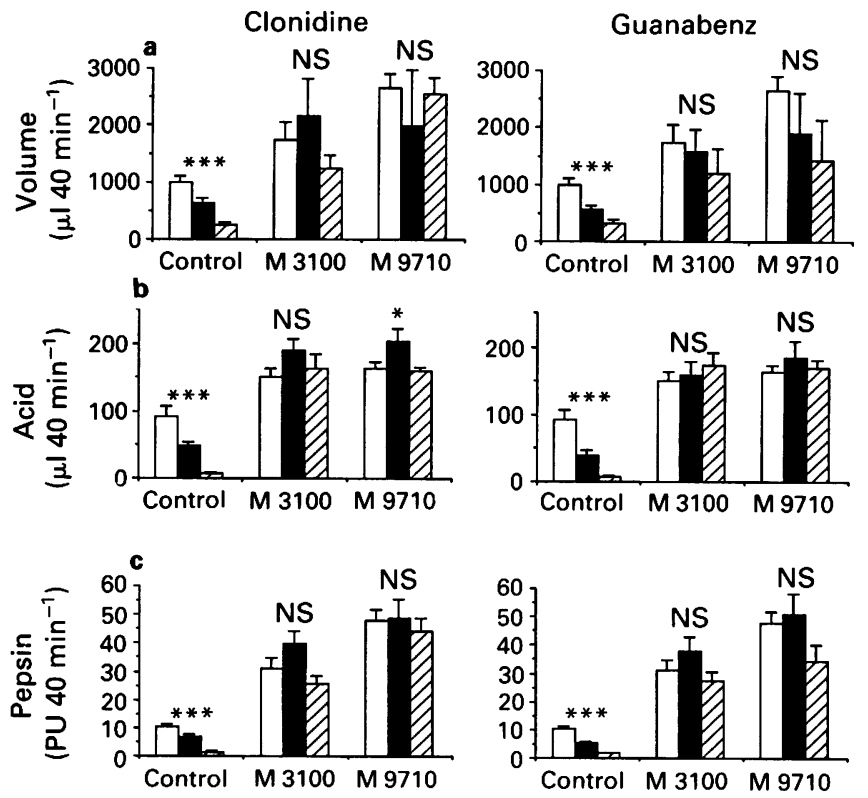

Figure 6 Effects of clonidine (left panel) and guanabenz (right panel) on gastric juice volume (a) and on acid (b) and pepsin (c) outputs in basal conditions (Control) and under methacholine (M) stimulation ( 3100 and $\left.9710 \mathrm{nmol} \mathrm{kg} \mathrm{kg}^{-1} \mathrm{~h}^{-1}\right)$ in conscious rats provided with gastric chronic fistula. The stimulation consisted of two successive $40 \mathrm{~min}$ infusions of methacholine 3100 and $9710 \mathrm{nmol}$ $\mathrm{kg}^{-1} \mathrm{~h}^{-1}$ from $120 \mathrm{~min}$ after the beginning of clonidine or guanabenz infusion. The doses of clonidine and guanabenz were: zero $=$ open columns; $13.7 \mathrm{nmol} \mathrm{kg} \mathrm{kg}^{-1} \mathrm{~h}^{-1}=$ solid columns and $43.5 \mathrm{nmolkg}^{-1}$ $h^{-1}=$ hatched columns. Means of 6 to 12 rats per group. Vertical lines show s.e.mean. NS $=$ no significant difference.

${ }^{*} P<0.05$ and ${ }^{* * *} P<0.001=$ values of the difference between the doses of clonidine and guanabenz $\left(0,1.37\right.$, and $\left.43.5 \mathrm{nmol} \mathrm{kg}^{-1} \mathrm{~h}^{-1}\right)$ under basal conditions (Control) and under methacholine stimulation (3100 and $9710 \mathrm{nmol} \mathrm{kg}^{-1} \mathrm{~h}^{-1}$ ) (ANOVA).

tamination, by use of the average data of methacholine stimulation of salivary secretion, shown in Table 4. This correction was also made in clonidine treated groups, since clonidine $\left(43.5 \mathrm{nmol} \mathrm{kg}^{-1} \mathrm{~h}^{-1}\right)$ did not change the methacholine-induced stimulation of salivary volume and bicarbonate output (Table 4).

Clonidine and guanabenz (13.7 or $\left.43.5 \mathrm{nmol} \mathrm{kg}^{-1} \mathrm{~h}^{-1}\right)$ did not decrease significantly gastric secretion (volume, acid and pepsin) stimulated either by a submaximal $(3100 \mathrm{nmol}$ $\left.\mathrm{kg}^{-1} \mathrm{~h}^{-1}\right)$ or maximal $\left(9710 \mathrm{nmol} \mathrm{kg} \mathrm{k}^{-1} \mathrm{~h}^{-1}\right)$ dose of methacholine (Figure 6). Clonidine $\left(13.7 \mathrm{nmol} \mathrm{kg}^{-1} \mathrm{~h}^{-1}\right.$ ) actually caused a slight increase in methacholine-stimulated acid output.

\section{Discussion}

The effect of $\alpha_{2}$-adrenoceptor agonists on gastric acid secretion has been studied in a variety of species, mainly by use of clonidine (Hoefke \& Kobinger, 1966; Cheng et al., 1981; Del Tacca et al., 1982; Pascaud et al.,1983; Soldani et al., 1984) but also with guanfacin, xylazine, guanabenz, detomidine and medetomidine (Kunchandy et al., 1985; Bernardini et al., 1986; Savola et al., 1989; Blandizzi et al., 1990). In those studies, small doses of clonidine usually induced an inhibition of gastric acid secretion when this secretion was stimulated by vagal activity or by pentagastrin. Such inhibition was also observed during basal and pentagastrin-stimulated secretion in conscious fistula rats (Pascaud et al., 1983), conscious pylorus-ligated rats (Cheng et al., 1981; Del Tacca et al., 1982; Bernardini et al., 1986), or 2-deoxyglucose stimulated secretion in rats and dogs (Cheng et al., 1981; Soldani et al., 1984). This inhibition has been interpreted as resulting from the action of clonidine at neural $\alpha_{2}$-adrenoceptors, located both peripherally (presynaptic $\alpha_{2}$-receptors on vagal acetylcholine-producing neurones, Del Tacca et al., 1982) and centrally (Taylor \& Mir, 1982; Pascaud et al., 1983; Dettmar \& Lord, 1986; Fornai et al., 1990).

In contrast, basal gastric acid secretion in preparations without endogenous vagal tone, such as basal secretion in lumen-perfused anaesthetized rats (Bernardini et al., 1986) or basal secretion in dogs (Soldani et al., 1984) was moderately increased by clonidine. This effect was suppressed by histamine $\mathrm{H}_{2}$-receptor antagonists, and has been attributed either to direct activation of histamine receptors, or to histamine release by clonidine. The non-imidazole derivative, guanabenz, did not display such stimulating effect (Bernardini et al., 1986). Recently, however, the selective $\alpha_{2^{-}}$ adrenoceptor agonist, detomidine, which lacks affinity for $\mathrm{H}_{2}$-receptors (Virtanen \& Nyman, 1985), has been found to stimulate gastric acid secretion in urethane-anaesthetized, lumen-perfused, non-vagotomized or vagotomized rats (Blandizzi et al., 1990). This effect was reversed by idazoxan and the authors suggested that it might correspond to the blockade by detomidine of an $\alpha_{2}$-mediated sympathetic inhibitory tone on the gastric secretion. In other studies, acid secretion stimulated by cholinergic agents was either unchanged (Pascaud et al., 1983, conscious rats) or even increased (Soldani et al., 1984, conscious dogs) by clonidine.

In contrast to these detailed reports of $\alpha_{2}$-adrenoceptor agonist effects on gastric acid secretion, no data have been published as yet concerning pepsin secretion. The present results show that basal pepsin secretion in conscious rats (an animal model submitted to permanent sustained vagal stimulant tone) was decreased in a dose-related way by the four $\alpha_{2}$-adrenoceptor agonists tested, with similar potencies (non significantly different $\mathrm{ED}_{50}$ values of 4.7 to $9.8 \mathrm{nmol}$ $\mathrm{kg}^{-1} \mathrm{~h}^{-1}$ on pepsin secretion) and efficacies (approaching $100 \%$ inhibition at the dose of $\left.43.5 \mathrm{nmol} \mathrm{kg}^{-1} \mathrm{~h}^{-1}\right)$. This $\alpha_{2}$-mediated effect (suppressed by idazoxan), was comparable for volume, acid and pepsin, and we suggest that it may be due to the occupation of either central $\alpha_{2}$-adrenoceptors or presynaptic $\alpha_{2}$-adrenoceptors located on peripheral cholinergic neurones. Since this inhibition of basal secretion corresponds to the suppression of an endogenous cholinergic stimulus, it does not implicate the presence of inhibitory 
Table 4 Effect of methacholine and methacholine plus clon
Methacholine
$\left(\mathrm{nmol} \mathrm{kg} \mathbf{~}^{-1} \mathbf{h}^{-1}\right)$

0

3100

3100

9710

9710

$\begin{gathered}\text { Clonidine } \\ \text { (nmol kg-1 } \mathrm{h}\end{gathered}$
0
0
43.5
0
43.5

on salivary secretion in conscious rats

\begin{tabular}{|c|c|}
\hline \multicolumn{2}{|c|}{ Bicarbonate } \\
\hline $\begin{array}{l}\text { Concentration } \\
\left(\mathrm{mmol} \mathrm{l}^{-1}\right)\end{array}$ & $\begin{array}{c}\text { Output } \\
\left(\mu \mathrm{mol} 40 \mathrm{~min}^{-1}\right)\end{array}$ \\
\hline $21.6 \pm 4.1$ & $2.1 \pm 1.2$ \\
\hline $39.5 \pm 2.2$ & $80.7 \pm 14.4$ \\
\hline $31.1 \pm 1.6$ & $71.6 \pm 11.1$ \\
\hline $42.0 \pm 1.2$ & $141 \pm 13.2$ \\
\hline $38.1 \pm 0.2$ & $144 \pm 15.3$ \\
\hline
\end{tabular}

$\begin{array}{cc} & \begin{array}{ll}\text { Ime } \\ \left.\operatorname{nin}^{-1}\right)\end{array} \\ & \\ & \pm 26 \\ 2 & \pm 470 \\ 2 & \pm 470 \\ 3 & \pm 240 \\ 3 & \pm 410\end{array}$

$38.1 \pm 0.2$
$P$ levels, 2 way ANOVA:

Between methacholine doses

Clonidine/no clonidine

Interactions clonidine/methach

Data are shown as the mean \pm s.e.mean of 4 rats per group

$\alpha_{2}$-adrenoceptors on chief cells. Thus, the simple decrease in acetylcholine efflux from nerve terminals to chief cells can explain the results.

The effect of clonidine and guanabenz was also tested on stimulated pepsin secretion, and we chose for these experiments CCK and methacholine, which probably are the two main physiological stimulants of pepsin secretion (Hersey, 1987; Tazi-Saad et al., 1992). The results were different with these two stimulants: whereas clonidine and guanabenz both decreased CCK-stimulated acid and pepsin secretion, they did not change (or even marginally increased) methacholine-stimulated acid and pepsin secretion. Since pepsin concentration did not decrease with increasing doses of $\alpha_{2}$-adrenoceptors agonists (Table 2), it may be that only the volume flow was decreased by $\alpha_{2}$-adrenoceptor agonists in CCK-stimulated gastric glands, thus preventing pepsin from being washed out of the glands. If the inhibition of CCK-induced secretion is due to the absence of cholinergic tone in gastric glands, the effects observed may be attributed to the central decrease of vagal tone and/or to the presynaptic inhibition of acetylcholine release by $\alpha_{2}$-adrenoceptor stimulation. Previous experiments comparing clonidine and ST91 a clonidine-like drug (which crosses the blood-brain barrier poorly) indicated that clonidine inhibition of gastric acid secretion in conscious rats had a large central component (Pascaud et al., 1983). Clonidine thus inhibited the effect of the central stimulant 2-deoxy-D-glucose, which acts through the vagus on muscarinic gastric receptors, whereas the peripheral cholinoceptor stimulant methacholine was not affected (Pascaud et al., 1983). It has also been shown that the volume and acid responses to pentagastrin are much decreased in vagotomized rats, and that most of the response

\section{References}

ANSON, M.L. \& MIRSKY, A.E. (1933). The estimation of pepsin with hemoglobin. J. Gen. Physiol., 16, 59-63.

BERNARDINI, C. DEL TACCA, M., SOLDANI, G. \& MARTINOTTI, E. (1986). The effects of $\alpha_{2}$-agonists and antagonists on gastric acid secretion. Arch. Int. Pharmacodyn., 281, 134-144.

BLANDIZZI, C., BERNARDINI, M.C., NATALE, G. \& DEL TACCA, M. (1990). $\alpha_{2}$-Adrenoceptor-mediated inhibitory and excitatory effects of detomidine on rat gastric acid secretion. J. Pharm. Pharmacol., 42, 685-688.

CHARIOT, J. \& ROZÉ, C. (1976). Détermination automatisée de très faibles concentrations de bicarbonate. Application au suc pancréatique. Ann. Biol. Clin. (Paris), 34, 269-272.

CHENG, H.C., GLEASON, E.M., NATHAN, B.A., LACHMANN, P.J. \& WOODWARD, J.K. (1981). Effects of clonidine on gastric acid secretion in the rat. J. Pharmacol. Exp. Ther., 217, 121-126.

CHICAU-CHOVET, M., DUBRASQUET, M., CHARIOT, J., LECOMTE. J.M. \& ROZE, C. (1988). Thiorphan and acetorphan inhibit gastric secretion by a central, non-opioid mechanism in the rat. Eur. J. Pharmacol., 154, 247-254. to pentagastrin can be restored by infusing small doses of acetylcholine, able to mimic a pseudo-endogenous vagal tone (Chicau-Chovet et al., 1988). This, however, has not been determined with CCK.

The effect of methacholine was not changed, or tended to increase, after clonidine or guanabenz administration. This suggests that the $\alpha_{2}$-adrenoceptor agonists did not interfere with the intracellular mechanisms activated by methacholine, and thus that the parietal and chief cell membranes do not bear $\alpha_{2}$-adrenoceptors able to interfere with the cellular processes when the muscarinic receptors of these cells are stimulated. Soldani et al. (1984) found in the dog an increase of both bethanechol- and histamine-stimulated acid secretion by clonidine. These authors suggested that this result was due to the histamine receptor stimulating effect of clonidine. The mechanism is probably different in our experiments, since guanabenz, which has no histamine-like effects (Bernardini et al., 1986) produced the same effect as clonidine.

In conclusion, we suggest that the effect of the $\alpha_{2}$ adrenoceptor agonists on both pepsin and acid is probably due to the central and peripheral inhibition of the neural cholinergic input to gastric glands. Some cholinergic background is necessary for developing the stimulating effect of various agents, which explains why CCK-stimulation is also inhibited by the $\alpha_{2}$-adrenoceptor agonists. When methacholine is used, it compensates for the inhibition of cholinergic background, and does not allow $\alpha_{2}$-adrenoceptor agonists to inhibit this secretion.

Financial support was provided in part by the Conseil Scientifique of Faculté X. Bichat and by Association Charles Debray.

DEL TACCA, M., SOLDANI, G., BERNARDINI, C., MARTINOTTI, E. \& IMPICCIATORE, M. (1982). Pharmacological studies on the mechanisms underlying the inhibitory and excitatory effects of clonidine on gastric acid secretion. Eur. J. Pharmacol., 81, 255-261.

DETTMAR, P.W. \& LORD, J.A.H. (1986). The effect of $\alpha_{2}$ adrenoceptor agonists on the acid secretory responses of rat isolated gastric mucosa to electrical field stimulation. Br. J. Pharmacol., 89, 361-366.

EMÅS, S., NYLANDER, G. \& WALLIN, B. (1981). Comparison of the dose-response curves for acid output to pentagastrin determined by two techniques on chronic gastric fistula rats. Digestion, 22, 94- 100 .

FORNAI, F., BLANDIZZI, C. \& DEL TACCA, M. (1990). Central $\alpha_{2-}$ adrenoceptors regulate central and peripheral functions. Pharmacol. Res., 22, 541-554. 
HERSEY, S.J. (1987). Pepsinogen secretion. In Physiology of the Gastro-Intestinal Tract, 2nd ed., ed. Johnson, L.R., Christensen, J., Jackson, M.J., Jacobson, E.D. \& Walsh, J.H. pp. 947-957. New York: Raven Press.

HOEFKE, W. \& KOBINGER, W. (1966). Pharmakologische wirkungen des 2-(2,6-dichlor-phenylamino)-2-imidazolinhydrochlorids, einer neuen, antihypertensiven substanz. Arzneimittelforsch, 16, 10381050.

KUNCHANDY, J., KHANNA, S. \& KULKARNI, S.K. (1985). Effect of $\alpha_{2}$ agonists clonidine, guanfacine and B-HT 920 en gastric acid secretion and ulcers in rats. Arch. Int. Pharmacodyn., 275, $123-138$.

PASCAUD, X., ROGER, A., GENTON, M. \& ROZÉ, C. (1983). Further support for the central origin of the gastric antisecretory properties of clonidine in conscious rats. Eur. J. Pharmacol., 86, 247-257.

SAVOLA, M., SAVOLA, J.M. \& PUURUNEN J. (1989). $\alpha_{2}$-Adrenoceptor-mediated inhibition of gastric acid secretion by medetomidine is efficiently antagonized by atipamezole in rats. Arch. Int. Pharmacodyn., 301, 267-276.
SOLDANI, G., DEL TACCA, M., BERNARDINI, C., MARTINOTTI, E. \& IMPICCIATORE, M. (1984). Evidence for two opposite effects of clonidine on gastric acid secretion in the dog. Naunyn. Schmiedebergs Arch. Pharmacol., 327, 139-142.

TALLARIDA, R.J. \& MURRAY, R.B. (1984). Manual of pharmacologic calculations with computer programs. p. 14. New York: Springer-Verlag.

TAYLOR, J.A. \& MIR, G.N. (1982). Alpha adrenergic receptors and gastric function. Drug Develop. Res., 2, 105-122.

TAZI-SAAD, K., CHARIOT, J. \& ROZÉ, C. (1992). Control of pepsin secretion by regulatory peptides in the rat stomach. Comparison with acid secretion. Peptides (in press).

VIRTANEN, R. \& NYMAN, L. (1985). Evaluation of the $\alpha_{1}$ - and $\alpha_{2}$-adrenoceptor effects of detomidine, a novel veterinary sedative analgesic. Eur. J. Pharmacol., 108, 163-169.

(Received November 28, 1991 Revised March 2, 1992 Accepted March 23, 1992) 